\title{
JESSÉ SOUZA: A RELAPSE INTO THE INTERPRETATION OF UNIVERSAL MODERNITY?
}

In this article ${ }^{1}$ examine the debate over Jessé Souza's interpretation of Brazilian modernization as selective in nature - that is, singular, distinct from the model of modernization inspired by European societies and the United States. This interpretation is explored here as a counterpoint to the reading of Sérgio Buarque de Holanda, Raymundo Faoro and Gilberto Freyre of the topic, all of whom supported the view that Brazil's Iberian origins prevented adequate modernization of our institutions and social behaviours. I stress the point that although Souza's work constitutes a fundamental landmark in Brazilian sociology and social theory, A modernização seletiva [Selective modernization] still exhibits remnants of the acritical vision of Brazil. I argue that it is a certain ambiguity in Weber's theory of modernity that causes the author to lapse into the same mistake, simultaneously rejecting the theory of backwardness while defending the concept of selective modernity.

From the outset it should be noted that the article is guided first and foremost by the idea central to historical sociology ${ }^{2}$ that the formation of each and every society obeys singular existential processes and dynamics, without, though, this fact precluding the apprehension of those elements that have become widespread and constant across the diversity of social developments. One of the key features of this new approach is to reject the idea of a process of universal modernization able to serve as a model for all societies, thus suggesting that this process evades the control of human actions. Now, this un- 
derstanding, insofar as it presumes that the direction of history is known a priori, not only renders human action impossible, but also the very setting of this action - history - in which it becomes designed and redesigned as an event, at once singular, contingent and unrepeatable. How can we comprehend social change if we set out from the premise that the history of events fulfils a telos, that the future can be read in the past, and that societies are a reflection of a universal ideal of society? Classical sociology, which strongly influenced the conceptions of modernity and modernization of the previous century, is full of examples that illustrate this historical deficit: Karl Marx, one of the social thinkers most attuned to history, predicted the end of capitalism and the inevitable rise of socialism; Émile Durkheim believed that the transition from traditional to modern societies had in fact taken place almost automatically, without conflict or resistance, and without any aspects or remnants of the past society persisting in the social structures and actions of the present; Max Weber - possibly the classical theorist who most contributed to historical sociology - could not contain himself either and assumed that the process of western rationalization would expand to all corners of the world. In his essay "The inventory of differences," Paul Veyne (I982: I78) questions these abstract universalisms, indifferent to temporal individualizations. He writes:

So the conceptualisation of an invariant permits the explanation of events. By operating on the variables, it is possible - starting from the invariant - to recreate the diversity of historical modifications. In this way, the non-thought is made explicit, and light is thrown on what was only vaguely conceived or scarcely intimated.

It is precisely this relationship between generalization (or the search for constants) and singularities, inherent to the approach developed by historical sociology, the philosophy of Michel Foucault, and to some extent the social theory of Max Weber, that enables us to comprehend, on one hand, that diverse modes of social formation and development exist, and, on the other, that sociology's task is to seek out what remains general or constant in the diverse modes of different societies. Consequently, this article is inspired by the critique of 'big things' (Rorty, 2007) shared by Weber and Foucault, their rejection of the so-called universal questions, the representative ideals. Among the questions that they pose we can list: What is the truth of modernized society? What is the determining character of each culture? How can true democracy be established? These are metaphysical questions, self-descriptions, discourses that, though presented as a universal truth, are merely interpretative names by means of which human beings from every era constitute their perception of the surrounding world and through which they act and reflect. In other words, these names are immanent to historical phenomena: they do not hover over them, determine them from outside, or pull them towards a predefined destiny; much the opposite, they are led by history. 
This historicizing of big things does not preclude the possibility of elaborating valid scientific discourses about societies and their events. In this process of elaborating some kind of 'positivity,' we can perceive subtle but clear differences distinguishing the two authors, Weber and Foucault. It is precisely through these differences that I shall look to isolate my own analytic perspective. First we can observe an initial convergence in the authors' interpretation of social reality: differences should be marked in relation to their identities when it comes to interpreting or describing a particular historical formation of an image of the world, a self-description or a device, in order to make the singularity of the whole appear (the phenomenon posed to difference). It is differences that are emphasized, therefore, not identities. These marked differences retrace the comprehension of phenomenal singularities, the description of the starting point of difference and the interpretation of the singularity of the empirical phenomenon, respectively. However, this initial convergence on a detail - though details are what is most important in these theories transforms into a clear conceptual divide when the authors turn to examine the same phenomenon and its analytic premises: modern society.

Unlike Weber, Foucault refused to generalize the discourse on the singularity of the phenomenon, even surreptitiously, although he recognizes its historical and empirical validity. As Paul Veyne (2010: 46) once said: "Leave little facts in peace, but make war on generalizations. As Foucault, this unexpected positivist, vouchsafes no more on this score, let me chance my arm." While Foucault (2002) remained entirely sceptical about the existence of big things from the very beginning to the end of his work, Weber did not recoil from what he saw as a scientific task, namely, the elaboration of generalizing and universal explanations of societies. Here, then, a question arises: when Weber affirms the inexorably universal condition of modern rationality, is he not producing generalizations that deny the phenomenal singularities or underlying perspectival differences? I believe so.

In Weber, this demand for generalization is clearly inscribed in one of his most important methodological concepts, the ideal type, whose central objective is to make a determined singular phenomenon as unequivocal as possible. Through his empirical studies, Weber shows how the comparative analysis of historical formations produces typical concepts: capitalism, Calvinist belief, the theodicy of salvation, and so on. The singular aspects of specific phenomena are multiple. It is left to the researcher to select and emphasize, based on his or her interests and values, which aspects to privilege and which to ignore. Most scholars of Weber's thought tend to conclude that the central interest driving him was understanding the modern phenomenon of rationalization. This concept assumes a key role in his comparative analyses of world religions, in his studies of modern politics, in his essay on music - in sum, throughout his intellectual trajectory. But above all it seems to be a general conclusion of his concerning the phenomenon of western modernity: 
A product of modern European civilization, studying any problem of universal history, is bound to ask himself to what combination of circumstances the fact should be attributed that in Western civilization, and in Western civilization only, cultural phenomena have appeared which (as we like to think) lie in a line of development having universal significance and value (Weber, 2001: xxviii).

Reading this introductory passage to The Protestant ethic and the spirit of capitalism, it is not difficult to note that the task of conceptual generalization induces the reader, and perhaps Weber himself, to downplay or even ignore the fact that although the phenomenon became universal in its effects and causes, this does not imply that its process of historical constitution has not been contingent and singular. For this very reason, it cannot be comprehended as a metaphysical entity capable of being coupled to other social formations, as though the type of society that becomes constituted at a particular time and place could provide a 'mirror' from which other societies can learn, ignoring the fact that involves processes that require human action, making them unpredictable, contingent and unrepeatable.

It is important to emphasize this point because this Weberian prerogative of defining a generalizing scientific semantics for modern societies has inspired worldviews, sociological theories and political practices that postulate the existence of an ideal and universal model of society to be copied by all other societies worldwide. In the immediate post-war period, sociological, political and economic studies of so-called peripheral societies became consolidated, especially in the United States. These studies were guided by the theory of modernization. In a nutshell, the theory of modernization argues that the technical and scientific rationalization forged in Europe and the United States would expand to all parts of the world as a model in which other societies would see themselves reflected. Max Weber's general conclusion, the expansion of western rationalization, appears almost as a teleological determination in this context, a naturalization of the inevitable progress of modern reason. Hence the theory of modernization tends to conclude that rationalization came to occupy the place of the universal and universalizable, the impersonal and the objective, the generalizing and decontextualized - that is, the place of what is valoratively ideal to be followed, contrary to what is shown to be contingent, contextual, singular, different, or, put otherwise, what appears to be a deviation, a mistake to be avoided. Reason thus appears as a positive factum of western modernity through which the processes of change developed via the functional differentiation of its institutions, the rationalization of its culture and the personalization of its individuals. This experience, which in Weber's view had an eminently peculiar and situated beginning, acquires an abstract and conditioning form capable of being adapted by other societies in present or future time and space.

This conception of modernization as an ideal model to be followed had and still has profound impacts both on the scientific interpretation of Brazil, 
on its everyday beliefs and on its political and institutional practices. The principal names involved in this interpretation are Gilberto Freyre, Sérgio Buarque de Holanda and Raymundo Faoro, who, despite the differences in their perspectives, reached a common denominator: namely, that Brazilian modernization has been slow compared to European and American modernization. This amounts to a typical case of what Bertrand Badie (I992) called overlapping histories - that is, the problem experienced by non-European societies guided at scientific and practical-institutional levels by two temporal constructs: one their own, endogenous; the other from the European world, exogenous. So when they elaborate self-descriptions and operate with interpretative models taken from European and American social theory, they tend to conclude that their own society's actualization the model is, by comparison, equivocal, backward, inferior. To paraphrase Roberto Schwarz (20I4), it is not the ideas that are out of place, but the place that is ill-suited to the ideas. Much of Brazilian sociology, however, became wrapped up in the notion that societies and their processes and dynamics follow a homogenous and universal line of modernization, such that all of them actualize some essential concepts: individualism, the separation of public and private spheres, liberalism, and so on. Once these commentators perceived that modernization in Brazil proceeded on bases divergent from those considered exemplary, they evaluated this process negatively.

The realization that ideas are not abstractions that can be transplanted from one place to another is clearly formulated by Jessé Souza (2000a) in A modernização seletiva: uma reinterpretação do dilema brasileiro. Overall, Souza ${ }^{3}$ concludes that the common interpretative baseline of these founders of the view of an atavistic Brazil is the notion that our Iberian origin prevented the adequate modernization of our institutions and conducts: modernization is defined and achieved by Europe and the United States. To critically challenge this entrenched interpretation of Brazil, Souza elaborated the concept of selective modernization, by which he means that here we developed the selective, singular type, different from the kind imposed as a model of modernization, that is, European societies and the United States. Brazil's peculiar condition, however, did not make it backward as the sociology of 'atavistic culturalism' believed: we are just as modern as any other society. But while this peculiarity of our modernization makes us no less modern, it certainly makes us a peripheral, negative and selective version of a particular idea of modernity. Since what is 'peripheral,' 'negative' and 'selective' is always so by comparison with the standard and the centre, we can presume that this concept of selective modernity defended by Jessé Souza is still aligned with a self-description (in theoretical terms) and a selfaffirmation (in practical and institutional terms) oriented by a particular modern ethos representative of the essence of societies. As a consequence, deconstructing the modern ethos as representative of the essence of human societies seems to me of considerable analytic value, providing that "all the cards are 
placed on the table" - that is, the persistence of its defence does not appear to drift away from the author's true intentions. Not least because he does not seem to be acting against science, nor in favour of "conservative political ideologies," by supposing that Brazil actualized the universal demand for modernization on the basis of specific and unique cultural premises.

Why, then, call this process a singular, selective and/or elective modernity or a negative modernity? When talking about modernity in European countries, why do we not speak of the selective modernity of England, France or Germany? This is important to register because Jessé Souza sets out from the premise that Brazil is modern yet, because of the way it was structured around inequality and social exclusion, the country developed the peripheral type of modernity. Now, as already observed, a concept is always affirmed in relation to another that is negated. This being the case, the above concepts require at least some kind of central and positive modernity. The question is: how can an interpretation that attempts to critically reconstruct the specificities of Brazilian modernization, purged of ahistorical explanations frozen in time, end up producing normative formulations that are not so different from the interpretative limitations critiqued previously?

The brief discussion that follows on Jessé Souza's conception of selective modernity takes as its central theoretical premise, as indicated above, the rejection of the ideal of universal modernity and the refocus on the notion that societies, whichever they may be, constitute singular processes of formation at the same time as they generate self-descriptions. Consequently, as I also observed earlier, ultimately it is the main theses of historical sociology that provide the basis for this critical study of Jessé Souza's interpretation. More precisely: it is the critiques developed by Bertrand Badie (I992) of the wellknown approaches of historical sociology itself that enable us to conjecture that even a theorist like Jessé Souza, a pioneer among us in the elaboration of a critical theory of modernity, stumbles when it comes to generalizing his analytic perceptions of the process and conditions of Brazil's modernity. This applies specifically to his book A modernização seletiva where he tries to persuade us that only modernization and the modernity actualized by Brazil are selective and singular. Furthermore, as appears more clearly in his book A ralé brasileira, he reminds us that this differentiated condition of Brazil is an outcome of the social, cultural and economic inequality that structure its process. In this sense, then, while we developed modernization like any other country, whether European or the United States, due to these individual conditions of inequality we are still modern in appearance only. The process was comparatively modern, but the current state of modernity presents deficient levels of structural modernization. This specific circumstance precludes any possibilities for social change and transforming social realities, since individuals are immersed in their structurally unequal conditions of existence. Illustrations of this are found 
in the case studies presented in A ralé, which inevitably refer us to the hypercritical situation of critical theory, given that there seems to be no solution for those immersed in these structures of domination and alienation. Weber and Bourdieu are, at this point in Souza's argument, his main guides with their familiar doses of pessimism regarding the tragedy of modern culture and the symbolic domination of capitalism, respectively.

Taking as a premise two fundamental elements to the sociological-historical investigation of social formation, the process of modernity and its current state, Jessé Souza's critique of a wide variety of interpretations of Brazil could be said to be guided by the general understanding that there is no universal ideal of society, European and North American, that all other societies should reflect in their individual processes. Likewise there is no explanation of the present contained in the past, as though the present obeys an internal or external logic from which it cannot escape and over which it has no control.

In Souza's view, all kinds of interpretations of Brazil, irrespective of whether they are culturalist (Gilberto Freyre and Sérgio Buarque de Holanda) or institutionalist (Caio Prado Júnior and Fernando Henrique Cardoso), share a common denominator in the understanding that an ideal definition exists of both modernity and the historical realities that share this ideal. Brazil, however, is in a situation of 'backwardness,' 'deviation,' 'marginality' and 'peripherality' vis-àvis this ideal. This raises the question: what ideal of modernity are we talking about? Where and from whom does it derive? Answering this question is not difficult. The tradition of Brazilian thinkers (including those active today) have been guided primarily by the hegemonic concept of modernity traceable in sociologists like Weber, Simmel, Parsons, Marx, Durkheim, Habermas and Luhmann, who, despite the insurmountable differences between them, shared the more general understanding of modern society, which can be summarized as follows:

a) State, market and civil society necessarily occupy mutually and fully differentiated spheres, regulated exclusively by their own codes and dynamized by particular logics; b) the normativity that regulates the relations between individuals and between them and the State and market are fully disenchanted, as well as protected from the influence of non-rationalized worldviews and normative systems; and c) the public and private spheres, for their part, are also fully separate, each ordered by particular codes and logics, communicating solely through appropriate channels that maintain unaltered the terms and rules of each of the domains (Tavolaro, 2005: I2).

This passage furnishes the three mainstays to the sociological epistemology dominating their conception of modern society. However, we need to add a fundamental element missing from the above definition: this configuration of modernity is universal. In other words, it expands to all corners of the world executing these steps, shaping cultural differences and imprinting the unequivocal logic of rationalization and systematic logic. But while these thinkers elaborated the concept of modern society through undeniably careful analyses of 
their own societies (basically European and American) and concluded that there was a universal symmetry to its process of increasing rationalization, especially at the level of the operation of their social systems (or orders or social institutions), they also allowed themselves to be swayed by the overwhelming power of their own creation: their concept of modernity. This concept, even in the case of thinkers possessing a deep historical sensibility like Weber and Simmel, to some extent ignores the elements contained in the event of modernity: change, contingency, singularity, chance, conflict and so on. In other words, it ignores the historical and sociological fact that contexts and their specificities, many of which are irreducible, shape so-called universal patterns.

Consequently, these thinkers, who served as a theoretical inspiration to Brazilian commentators, also failed to perceive that the processes of modernity and modernization realized by European societies reflected their own singularities and differences. One such example is the historical fact that Puritan colonists from England settling in American lands - who presumably shared similar cultural, social and political practices - constituted a modern society with very different parameters to those established in their society of origin. Other examples exist, based, indeed, on irreproachable analytical sources, as in the case of Tocqueville's analysis of the distinct nature of the modernization process of American institutions compared to their French counterparts, the analysis of Norbert Elias (to whom I return later) on the peculiarities of the German civilizational process compared to what unfolded in France and England. In sum, various examples corroborate the importance of the variable of singularity, context and difference for understanding the modernity of any given society.

Comprehending these details is fundamental, since the argumentative baseline of the most important theorists of the so-called I930s generation - that is, those who exerted a strong influence on the scientific interpretation and everyday sense of modernity in Brazil - is strikingly cultural in kind. This culturalist perspective, shared by these interpretative approaches, is maintained largely as a result of the way in which Weber's theory of modernity was received in Brazil (Vianna, I999: I74). This is explained by how Weber constructed his theory, strongly based on a heuristic comparison of distinct historical realities as a means to discern the set of elements that singularized the advance of the modernizing process of western societies compared to a lower reach of this same process in eastern societies. Unlike the economic emphasis displayed in Marx's approaches, his analysis also focused on the form in which this increasing rationalization was motivated by determined cultural practices in tune with the emergence of social orderings (capitalism, bureaucracy, the rational State, and so on). Weber's starting point, therefore, is cultural, although he repeatedly made the point that his intention was not to invert Marx's analytic perspective: the internalization and actualization of a pattern of rational life collaborated in the institutionalization of modern reason. 
Weber - and it is important not to forget this point - analysed singular contexts, including singular comparative elements, in order to then elaborate ideal-typical generalizing concepts. He also repeatedly affirmed that his concepts were valid within the context of his own research and should not, therefore, be used in other studies since there were the result of the relation between the "specifically unique and individual character" of social phenomena. Thus he wrote the following in one of his works, The Protestant ethic and the spirit of capitalism, where we can most easily perceive the instrumentalization of his methodological and epistemological conceptions:

Such an historical concept, however, since it refers in its content to a phenomenon significant for its unique individuality, cannot be defined according to the formula genus proximum, differentia specifica, but it must be gradually put together out of the individual parts which are taken from historical reality to make it up. Thus the final and definitive concept cannot stand at the beginning of the investigation, but must come at the end. We must, in other words, work out in the course of the discussion, as its most important result, the best conceptual formulation of what we here understand by the spirit of capitalism, that is the best from the point of view which interests us here. This point of view (the one of which we shall speak later) is, further, by no means the only possible one from which the historical phenomena we are investigating can be analysed. [...] The result is that it is by no means necessary to understand by the spirit of capitalism only what it will come to mean to us for the purposes of our analysis. This is a necessary result of the nature of historical concepts which attempt for their methodological purposes not to grasp historical reality in abstract general formulæ, but in concrete genetic sets of relations which are inevitably of a specifically unique and individual character (Weber, 200I: I3-I4).

It is this theoretical nominalism, entirely consistent with his methodological premises, that is announced in Weber's texts. However, it is not maintained in his final conclusions, since in the same work Weber (I998: I30) forgets the random historical-cultural events that gave rise to modern formations, particularly capitalism, when he affirms their universally expansive condition. Perhaps the commentators of Brazilian modernity would not have lost anything in analytic refinement in their appropriation of a classic of Weber's stature especially when this appropriation is made so in order to compare his ideas with the specific contexts in which they are instrumentalized, if - and only if - they had perceived the critical distance between his nominalist cultural conceptual base and his universalist historical diagnosis. Now, if we encounter in Weber himself this contradiction that appears to annul the differences in rationalization between cultures on the premise that Protestant asceticism "reshaped the world," it should be no surprise to find a society that describes itself as one that developed a 'backward,' 'peripheral' and 'selective' modernity.

Situating Brazil in the same western civilizing formation as nations like Germany, Britain and France, however, still tells us little about the process by which it became a more modern society, since the sharing of more general and 
universal values does not contribute decisively to shaping societies in symmetric processes of rational standardization of their individual and collective actions. This is also why comparing Brazil with a nation like the United States - presented as an ideal of modernized society in the eyes of its intellectuals and institutionally circulated reaching public opinion - despite its geographic proximity and the development of a degree of synchrony in its processes (the decimation of its native population, slavery and so forth) does not imply that its modernization processes had to occur simultaneously and required identical cultural practices. Not least because substantial differences also exist even among the processes of societies considered models of modernity: Britain, France, Germany, the United States. As Jessé Souza (2000b: 89) reminds us, the latter exerts its difference through its self-description as the bearer of cultural and institutional values the provide a model of modernity.

Given the above, when Weber is invoked in the debate on Brazilian modernity, it is not the complexity of his theory as a whole that is under discussion, nor a critical appraisal of its limits and analytic errors, but the selection of conceptual elements that legitimize a preconceived notion of what a modern society is and what type of culture is best suited to its expansion. This relationship between Weber's theory of modernity and its instrumentalization in the analysis of the process of Brazil's formation is not, therefore, a minor issue, but one that provides decisive clues for a critical apprehension of particular interpretations and their practical and political uses. It should be emphasized that during the period when the production of the view of Brazilian modernization as backward and singular was at its peak, namely between the I930s and I950s, it was common for its main theorists to conclude their texts with proposals for solving the supposed Brazilian dilemma. Thus the blurring between social science and social critique was a necessary chapter in the writings of its authors. But what takes on a much more important dimension is the fact that these proposals escaped the confines of writing and invaded the physical and symbolic world of government programs (Souza, 20I I: 37). Consequently, describing the analytic use of the concept of modernity informing these self-descriptive tendencies of Brazil - its flawed modernity and its unparalleled singularity - can help reveal their valorative motivations and their scientific misconceptions.

While the inspiration for these authors, especially Jessé Souza, from whom we shall develop the argument of selective modernity, is the Weberian notion of modernity, it makes little sense to resort to this kind of formulation. According to Jessé Souza (2000a) himself, the concept of modernity mobilized by Buarque de Holanda is not, essentially, that of Max Weber. The latter makes clear that what emerges strongly in the comparison between cultures are their singularities - that is, the characteristics that make one culture different from another. Indeed it is this difference that made this culture possible in one way and not in others. For Weber, a logic of development exists that traverses cul- 
tures, a logic defined ever since the Ancient Greek discovery of reason and extensively actualized by western cultures until reaching its most complete definition under modernity. This actualization, however, happened and still happens in the most diverse ways possible: here it suffices to recall that we do not need the rationalized culture of Calvinist communities to develop a certain pattern of subjective (internal) and objective rationalization (on the way to institutionalization) during the period of the rise of cities in the Medieval west (Weber, 2002). It was cities that promoted civil autonomy, non-legitimized democracy and trade, mainly through the rationalization of religious practices. But even so, Italian cities evolved in a different way to French and English cities, though they were equally moving towards an increased and more complex rationalization of their practical and theoretical domains. When this moment was partially suspended due to the emergence of the patriarchal and patrimonial State in all these cities, Weber does not refer to the 'delay' in the process of rationalization, but rather to the selection of ideals that informed the social, economic and political interests of dominant groups in the social hierarchy.

On this point, indeed, Jessé Souza has highlighted the fundamental question in Weber: the historical process invariably occurs as a process of domination and is simultaneously accompanied by a process of legitimization of the latter; although they do not happen in a planned or intentional form, the contingencies are, in each case, completed by an internal logic that designs and redesigns the general and specific framework of societies. In all events, while there exists this selectivity in the cultural processes actualizing the cognitive patterns of development, Weber at no point in his argument needed to emphasize that in suchand-such society modernity was selective, or more or less selective than in other societies. Being selective is precisely how cultures follow their course. This being so, it would not be a peculiarity that in the United States, for instance, a more ample and quicker rationalization of society was selected even before the State emerged; or that in England selection involved a more concomitant evolution of these two spheres. In sum, being selective is a characteristic inherent to every culture, not to Brazilian culture specifically. Why, then, consider Brazil to be the country that developed a selective modernity compared to western cultures? What prompted Jessé Souza to develop this line of argument?

In his book A modernização seletiva, he makes clear that this concept initially arose out of his critique of the 'atavistic culturalism' of the 'sociology of inauthenticity' developed principally by Sérgio Buarque de Holanda, 4 Raymundo Faoro (20I I: 822) and Roberto DaMatta. ${ }^{5}$ Secondly, and perhaps most importantly, he states that he was inspired by Gilberto Freyre's conclusions concerning the 'Europeanization' process of the nineteenth century, extensively discussed in his book Sobrados e mucambos (1936). It should be emphasized, therefore, that the conception that Brazil developed a selective modernization is not only inspired by Weber, but mainly by Freyre, who was the first, in Souza's 
view, to perceive that Brazil is modern, but modern in a singular sense because it was constituted through contextual aspects distinct from those selected by other realities. This is why Freyre does not appear in the aforementioned work as one of the representatives of the atavistic type of Brazilian sociology.

According to Souza, the central source of the sociology of inauthenticity is the idea that the constitution of western modernity is unequivocal and universal: in other words, these thinkers of Brazil were guided by the theory of modernization and thus believed that Brazil is not modern because it failed to adequately and authentically internalize the values of modern culture. The primary cause of this cultural inadequation is its Iberian origin. Thus, if we in Brazil fail to reflect, ipsis litteris, the European type of modernity, then we are not modern. Certainly, I think that Souza refutes this ideological and limited vision of modernity, reminding us that social and cultural modernization meant a process through which individuals defined conducts regulated by the internalization of civilizational standards. The paths constructed by societies to attain this standard, however, are neither the same, nor simultaneous. They depend on the 'selective' form by which each society, more specifically its dominant social class, defines what is modern and civilized, and, inversely, what should be avoided as pre-modern and uncivilized. The modern and the civilized are not a work of nature, a deus ex machina of historical determination; they are constructed within historical processes. Modernity is not a substantive entity, as I pointed out earlier, but a discourse in the best Foucauldian sense. Moreover the discourse that becomes dominant results from the interests of those groups holding power, which makes it impossible to separate values from their social institutions, their system of reproduction and their system of social stratification, as though they were detachable from their constitutive realities and could be transplanted into other realities. Contrary to what the sociologists of inauthenticity believed, Souza observes, Brazil's social institutions were merely continuations of those that had already existed in Portugal. However, we should add, just as the Portuguese colonist, his child or grandchild, were not the same 'plastic' Portuguese adventurer who landed here in I500, as Souza suggested in echoing this class interpretation by Gilberto Freyre. Jessé Souza (2000a: 252) states numerous times that "values are not transported like clothes," but we can add that history, as Weber affirmed, is not a tram that can be stopped whenever you want and that normally we do not make history in the way that we wish, as Marx (I997: 2I) almost lamented in The Eighteenth Brumaire of Louis Napoleon. The human beings who act in history are, invariably, swept along by contexts and social structures that forever escape their ability to control.

As we have already seen, the author of A modernização seletiva drew inspiration from Gilberto Freyre in order to argue for the singularity of a Brazil formed through the reaction to its historical particularities. And this event had a date of birth: in I808, sometime after the French Revolution (I789), the "mod- 
ernizing and bourgeois Brazilian revolution" (Souza, 2000a: 250) had begun. This hypothesis of revolution is inspired by what Freyre more circumspectly called a 'Europeanization' process, which was not limited to the skin-deep aspects of civility (such as Holanda thought), but, on the contrary, extended to the institutionalization of market values and the State. Since then, Brazil has not worried itself endlessly over various possible valorative codes: it finally defined its dominant code, namely, the code that provides the basis of modern western culture: universal moral individualism. "Values are not transported like clothes." Perhaps this is now the moment to repeat this phrase as a mantra so that its creator can hear it: by identifying a bourgeois revolutionary process in nineteenth-century Brazil and the consequent general introjection of universal moral individualism into its institutions, Souza, seems to me, at the very least, to adopt the position of someone who believes that not only values, but also ready-made social structures, can be transported. Here it is worth citing a paragraph in its entirety in which the author claims that Brazil, like the European nations and the United States, had fully developed "the cultural realizations of western modernity":

Contrary to what DaMatta thinks, since the modernizing revolution of the first half of the nineteenth century, Brazil has just one dominant valorative code: the code of western moral individualism. Individualism as a moral value -not to be confused with the empirical individual, common to all societies during all periods - is the alpha and omega of all the cultural realizations of western modernity, spanning from the competitive capitalist market to the liberal democratic State, and passing through the free press, rational scientific discussion, the doctrine of subjective rights and any of the other gains or positive aspects that we may imagine stemming from the passage from traditional to modern society (Souza, 2000a: 254, original italics).

This does not mean, however, that Brazil turned into a "modern, wealthy and democratic country" in the same way as other modern western countries became. Its modernizing revolution was not accompanied by democratic access to its cultural, economic and political assets. Even so, Jessé Souza apprehends the positivity of the event and immerses himself in it, driven by his keenness to emphasize that Brazil is just as modern as any European country. This explains why he develops arguments that even contradict his own starting point: namely that Brazil had developed a selective modernity, and, if it is selective, then it placed in motion modernizing elements distinct from those practiced by France or England. It seems to me that inverting the argument made by the 'sociology of inauthenticity' is unproductive or, at least, does not produce the critical and coherent result expected.

Jessé Souza, however, oblivious, pursues his project of defending Brazilian modernity. To this end, he takes from Freyre's Casa-grande \& senzala the process of overcoming a patriarchal era ${ }^{6}$ in which the landowners and slaveowners reigned supreme, unconcerned to give way to the social westernization in 
which bastard children, the mulatos, were rising socially, culturally and economically, becoming the avatar of impersonal modernity. For Souza, the Portuguese/Moor roots to Brazilian slavery, contrary to what Buarque de Holanda had imagined, ${ }^{7}$ possessed a pragmatic and functional particularity that rejected the essentialist premises of being white and male in order to place the focus on feeling white and acting as a man. Thus, if the illegitimate son knew how to act as and felt himself to be a white male, this was sufficient for him to be treated practically as an equal. By itself, this formulation of Freyre (I992: 272) had already instigated much discussion. ${ }^{8}$ Among the more interesting possibilities, we can ask whether there is any underlying Weberian inspiration and, if not, why associate it with western moral individualism? Freyre has clearly pragmatist analytic tendencies, since he centres on social contexts, rather than conceptual universals, and rejects the premise of cultural 'perfection,' formulations present in Weber's reading of the western world. Universal moral individualism - the Weberian concept elaborated through his analyses of the Puritan agent who internalized values of self-containment and externalized the rational domination of the world - does not seem to be the most consistent outcome of this pragmatic process of social ascension. This is because Weber constructs this concept in line with the Kantian legacy: it is the mark of a historicization of universal reason insofar as it is not given to us a timeless faculty but constituted through a processual dynamic that reached a fundamental moment of its history in which rational choices can be made for action: this moment, according to Kant (I974), just as for Weber, was the Aufklärung, the Age of Enlightenment.

Weber's reply to the question "why was the modern person able to divest himself of enchantments and adopt an ethical and responsible form of behaviour?" is thus: because the actuality of the present provides the possibilities for this conduct to become established and even spread to all parts of the world. When Jessé Souza, informed by a Weberian conception of modernity, believes that what makes Gilberto Freyre the shrewdest commentator of Brazil is this apprehension of the precise moment when Brazil also acquired these possibilities and triggered the same modernizing and civilizing mechanisms of universal moral individualism, he 'over-Weberianizes' Freyre's argument. And this Weberianization of Freyre means that the basic fact in the argument in Casagrande \& senzala and Sobrados e mucambos - namely that Brazilian modernization conformed to its Moorish-Slavery inheritance and its singular type of social stratification - the emphasis on singular contexts of modernity appears as one explanatory fact among others.

For Freyre, it seems to me, Brazil's modernization had developed in such a particular way that even during the decline of rural patriarchalism and the rise of urban social life in the nineteenth century, there was a certain transfer of patriarchal power from the master of Casa-grande \& senzala to the bourgeois 
master and trader from the Sobrados e mucambos. So how can Freyre's analyses be invoked to support of the theory that, already in the nineteenth century, Brazil had activated its modernizing revolution?

Before Souza's investigation takes this turn, however, I agree with at least two of his analytic premises: the first is that western modernity can assume singular configurations in accordance with the context that constitutes it; the second is that this singularity appears in the 'selective' form - I prefer to call contingent - with which each culture elects the social structure that will correspond to the flagship of modernization; examples include the United States choosing civil society as its base, while France identified one of its main allies of modernization in its political force. What would Brazil's particularity be, in Souza's view? It continues to be the same 'atavistic culturalism' that he himself criticized in the sociology of inauthenticity, insofar as he reprises the idea of Portuguese and Moorish slavery as the predominant vectors influencing Brazilian modernization. If the Portuguese who arrived here were not the same medieval Iberians who had visions of paradise, they were certainly not slavers typical of Moorish slavery either. If this argument is unconvincing, what can be said of the argument that endorses, with a certain elegance, the idea that Brazil entered the select world of modern nations via a patriarchal society that allowed the social ascension of the mulato, generating a modern bourgeois revolution. It is true that, on one hand, in support of this conclusion Souza cites a Weberian idea difficult to contest: values are not separate from their institutions. In other words, the values of European modernity that penetrated nineteenthcentury Brazil reconstituted its social institutions by valorising impersonality, requiring workers who were willing to "engage in the endeavour of modernization," irrespective of colour. At the same time, though, he produces hasty analytic generalizations and historical results that seem to forget the fact that values are not transported and, above all, are not adapted to varied contexts without themselves and the institutions formed by them undergoing profound alterations. Evidence of this forgetting is found in the following passage:

In a certain sense, however, selectivity does not seem to be merely a discontinuity provoked by the modernizing revolution at the beginning of the nineteenth century. It has a secular connection, five-hundred years old, with the Islamic slavery that became established here. After all, the subordinate who adheres to his father's values will still be the only one to be rewarded with benefits and favours. With modernization these values undoubtedly transformed from personal to impersonal in a shift from the traditional European father represented by the Portuguese to the impersonal father of the capitalism brought by European nations at the forefront of this process, but something of the initial logic is maintained (Souza, 2000a: 266, original italics).

It seems difficult to argue with the assertion that Brazil is modern - and modern not just in superficial appearance, but in its social structures. The idea that patriarchalism was a formative dimension of Brazil superseded by the rise 
of some mulatos to higher social strata, however, is an interpretation that overlooks an important aspect of Weber's theory of domination. According to this theory, an intrinsic part of the central power of the patrimonialist state, and consequently the patriarchalist state as well, is to promote members of lower strata due to their greater willingness to obey than those belonging to the higher strata. And this was a demand from the other side of the process of patrimonialist domination - that is, from the forms of legitimization created to maintain its power. A discussion of how social stratification produces ideas and processes that legitimize domination is, of course, fundamental to understanding any social formation, particularly the Brazilian formation whose structure of stratification is still strongly linked to the patriarchalist model. This being the case, it seems to me that Souza's argument - when focused, particularly in A modernização seletiva, on the claim that patriarchalism's culture of 'favours' provided the basis for the modernizing revolution in Brazil - wants of a more refined and critical analysis.

At this point in the argument it is useful to return to Souza's conception of modernization in order to comprehend this limit to his critique. In using the expression selective modernity, Souza obviously does not mean that the historical process, whichever it may be, involves a conscious, rational and planned 'selection' of certain elements at the expense of many others deemed less important. On the contrary, his aim is to salvage the sense of contingency, contextuality and chance intrinsic to the history of societies. Souza takes this insight, one of incalculable heuristic value and displaying a profound sensibility towards history, from Norbert Elias, who, in the majority of his texts, stressed the selective nature of the civilizational process. This can be perceived through the difference between Elias and Weber, as Souza (2000a: 43) highlights. Unlike Weber, who invests in the comparison between western societies and the rest, emphasizing the advancing rationalization and simultaneously waning irrationalization in the former, Elias is concerned with stressing a certain persistence of civilizing development coordinated by the requirements of privilege and distinction (Souza, 2000a: 49). Various possibilities exist for accessing modernity, therefore, keeping in mind that rationalization, rather than assuming the lead role, becomes dependent on the way in which each figuration (each society) develops the relation between social constraint and habitus. In this sense, contrary to an interpretation that posits rationalization as the inescapable direction of history and rationality as the ultimate meaning of civilization - so particular to Weber's analyses - Elias flatly refuses to understand western development as a homogenous, universal or unambiguous standard for the rest of the world, functioning as its cultural mirror. Instead, paradoxically, he emphasizes its concrete, specific and selective formations - that is, its processes of civilizing modernization.

It is precisely this insight, strongly present in Jessé Souza's concept of selective modernity, that enables us to stress one of the most fertile aspects of his 
texts: the ever-present possibility for us to understand modern societies through careful critique in line with the principles of scientific knowledge. It is notable that Souza partially allows himself to be lured by a certain 'ideal' of western modernity, particularly through the Weberian readings of the western world, visible earlier when we highlighted his urgent insistence on referring to Brazil's modernizing revolution, the rise of modern individualism and the values of impersonality as though it were these elements of western European culture that, de facto and de jure, conferred modernity to the singular Brazilian process. Notwithstanding their value as a procedure of comparison with other modernizing western processes, these elements lose much of their strength if we fail to heed his critique of generalizing, universalist and entrenched formulations of civilizing modernity, so as to consider that even the modernizing processes developed by Europe and the United States were selective, singular, unrepeatable, as can be perceived with the Brazilian experience. Consequently, the theoretical demand for a normative standard of culture, society and modernity is excluded: all that exists are empirical contexts that actualize a particular historical path that unfolds, irrespective of any examples or idealizations, through conflicts whose institutionalized outcome as a social rule or habitus matches the interests and ideas of the groups in power. This is factor of major importance when it comes to thinking about civilizing practices: what is considered civilized and/or uncivilized in each time and place depends on the social groups that win the dispute for distinction (Elias, I994; Bourdieu, 20 I I).

This is a lesson that Jessé Souza explores with acumen. However, as Orlando Villas-Bôas Filho astutely pointed out, ${ }^{9}$ his decision to adopt Freyre's interpretation of the transition from patriarchalism to modernization through the selective process of hybrid slavery (Souza, 2000a: 242), which suggests that the master had 'allowed' the revolutionary rise of the mulato to the middle strata of society, seems to lead him to forget that historical processes are not permitted nor even made possible by the group in a position to impose the measure of society. In my view, it is the reverberation of Freyre's conclusions in Souza's work that cause the latter to deviate from a truly critical comprehension of Brazilian modernity since they tend to obscure one of the most important analytic premises of his critical sociology: societies and their processes of constitution result from conflicts of interests and ideas between groups competing for social control. Thus an important event in a society, like a modification in the system of social stratification, cannot be simply understood as a 'negotiation,' a greater 'benevolence' or even a greater 'kindness' of one social stratum vis-à-vis another (Souza, 200ob: 244).

In truth, if we take the critical details of Souza's conception of modernity as a baseline, especially his perception that social processes are based on unequal social relations, it would be much more productive to draw inspiration from Sérgio Buarque de Holanda than Gilberto Freyre - for the reasons presented above. In support of this argument, we can highlight elements from the interpre- 
tation developed by the author of Raízes do Brasil that can be approximated to some of the assertions of the author of A modernização seletiva: I) although Buarque de Holanda supports the thesis of Iberism, he does not adopt the entrenched approach that Jessé Souza correctly identified in Raymundo Faoro; 2) his vision of history between historicism and the history of mentalities (Blaj, I998: 3I; Dias, I998: 22) enabled the understanding that the formative processes of societies are discontinuous and subject to profound alterations, precluding the idea of permanent values; 3 ) this vision provided him with a critical perspective later amply developed with the reading of Brazilian modernity as one that became structured around social inequalities; 4) the structuring of inequalities one of the central issues of Brazilian modernity - that resulted from the high concentration of wealth, power and culture, and developed in the traditionalist past, made it difficult, in his view, to accentuate the modern world at the expense of the traditionalist world of slavery and the landed aristocracy; 5) this past rooted in hierarchies and privileges allowed Brazil to successfully naturalize social inequalities; 6) finally, the process of modernization and Brazilian modernity did not take place, however, without social conflicts and political struggles; ${ }^{\text {Io }}$ there was an internal demand to redefine existing social structures and power relations.

My point can be summarized as follows: like Gilberto Freyre, Buarque de Holanda looked to learn from Brazil's conditioning cultural factors without considering them to be a priori forms of armour plating that were impossible to divest later. Buarque de Holanda's analyses include an essential proviso, announced above, namely that the social formation of the Brazilian past constituted a particular social structure of inequality and exclusion that makes it difficult for Brazil to become stabilized as an effectively modern country - but I stress difficult, not impossible. This is important to note because not just Jessé Souza, but a whole spectrum of contemporary authors ${ }^{\mathrm{II}}$ set out from the premise that Brazil is modern, but that, die to its structuring around the inequality of economic, social and cultural conditions, it developed the selective, peripheral and even negative type of modernity. This critical analysis is amply explored in A ralé brasileira: quem é e como vive (Souza, 20I I) and in A tolice da inteligência brasileira: ou como o país se deixa manipular pela elite (Souza, 20I5). These books generally seem to continue his particular line of studies, primarily begun with the publication of A modernização brasileira. His critique of the classic interpretations of Brazil once again underlies his argument and undoubtedly contributes to the definition of what he takes to be the central problem to be considered in Brazilian modernity, namely the problem of inequality and social exclusion. The question that accompanies him is: what mechanisms lead to the formation of the socially numerous group of people living on the edge of the economic and moral preconditions needed to compete for the 'best places' in all kinds of social, political, economic and cultural spaces? This form in which Brazilian society is structured - that is, through the distinction between one class, the ralé, the riffraff, "excluded from all physical and sym- 
bolic opportunities and all the other social classes that are, albeit differentially, included" - results in the main obstacle for Brazil to become an effectively modern country. What interests me in Souza's analysis, especially here, is his discussion of the causes of this limit to Brazil's modernity: rejecting the explanation of the Iberian origin developed by the authors of the 'sociology of inauthenticity,' he develops the thesis of 'selective modernity,' according to which the Brazilian process of modernization was devoid of a traditional morality comparable to the morality that structured the European societies and was shaped by a recent past of slavery that still has living implications in the present. Souza discusses this thesis in detail in order to stress the fact that, here in Brazil, certain aspects were privileged in detriment to others, for example, the personal aspect in detriment to the impersonal (Souza, 2000a: 258), the specific type of "Islamic slavery associated with the peculiarity of the essential inhumanity of the slave," despite the type of slavery effected by American modernization and the like. In A ralé brasileira he writes:

Rather than the classic opposition between workers and the bourgeoisie, what we
have here, in a peripherally modern society like Brazil's, as our 'central conflict,'
both social and political, one that overrides the importance of all others, is the
opposition between a class excluded from all physical and symbolic opportunities
for social recognition and all the other social classes that are included, albeit
differentially. While Brazilian society remains oblivious to this challenge, we
shall always be moderns in appearance only, a faltering, unjust modernity, pettily
economic and economicist (Souza, 20Ir: 25 ).

It is impossible not to agree with Jessé Souza (20I I: 25) concerning the need for us to develop "a radically new perception of the central problems that challenge Brazil as a society." However, while the perception must be radically new, we cannot simply repeat the old concepts and analyses in different guises, including here the concept of selective modernity, which repeats the same normative and idealized dimension of universal modernity criticized by the author himself. Bertrand Badie (I992: 344) argues that one possible explanation for the difficulty that sociology, historical sociology included, faces when trying to escape this historical shortfall in the interpretation of so-called dependent societies derives from the fact that these societies:

are marked by the overlapping of two histories and, in addition, two constructions of time: their own and that of the western world. The social dynamic of dependent societies is deeply marked by this duality: the importation of practices and models political, economic and social - is equivalent, at the same time, to the importance of another history and also leads to the coexistence of two histories.

From the viewpoint of his interpretation of Brazil's process of modernity, Jessé Souza positions himself a resolute critic of this importation of a universal ideal, stressing that every society, including Brazil, obeys its own individualities, its own idiosyncrasies, the specific actions and practices that 
direct its evolution. And this is why his critical sociology rejects any idea of trajectory, as a single abstract line of development, determining social realities; he also rejects the idea that the present or future of a society - the structuring of its social dynamic, its culture and its politics - results necessarily or dialectically from its past. He thus rejects the idea that Brazil is not modern because of its Iberian past. From the viewpoint of his interpretation of how the Brazilian social dynamic, its institutions and social systems, is structured, however, we can observe that Souza makes the same kind of mistakes that, Badie (I992: 346) suggests, we find in other thinkers from historical sociology like Theda Skocpol and Perry Anderson - notably the theoretical mistake of thinking that Brazilian modernity is defective (or deficient or negative) because its social dynamic is marked by social inequality, which, unlike other societies with which it is compared, is so extreme that it impedes the normalized establishment of modern institutions like democracy and citizenship. Primarily taking Bourdieu's theory of symbolic domination as a baseline, therefore, Souza argues that the form in which the institutional profiles, class practices and individual actions are reproduced and transform ultimately obeys the logic of capital, power and information embedded in economic, political and cultural capital respectively. Moreover, this reproduction, functioning at both a macro level of social institutions and systems, and a micro level of social actions and practices, continues its modernizing course in peripheral societies, like Brazil, without the consequences of its modus operandi interfering in its development.

The undeniable merit of Jessé Souza's thought needs to be emphasized, especially his powerful critique of the 'naturalization' of the inequalities rife in peripheral societies. We are modern, but unequally modern. And the condition of inequality is produced and reproduced by the structures of modernity. It is not this condition, therefore, that makes us more or less modern, but the fact that we have developed a 'precarious habitus,' one that characterizes, in fact, both central and peripheral societies. Here, though, the system of exclusion is even more dramatic and accentuated. This concept, elaborated by Souza through a consistent synthesis of Taylor and Bourdieu, reflects a certain pattern of action of individuals and groups disconnected from the demands of capitalist utilitarianism, which impedes these individuals or groups from being recognized in terms of their capacity to be productive, their dignity as a citizen. It should be emphasized, furthermore, that this precarious and highly unequal dimension characteristic of our social dynamic ensures its perpetuation in a vicious cycle, since its conditions of reproduction are found at the very base of modern structures. Consequently, Jessé Souza moves to the hypercritique of Bourdieu, inducing us to think that this vicious reproduction of the structures of domination of modern society makes any transformation of practices, and thus the conquest of freedom, impossible. If this interpretation of Souza is correct, his critical theory - in general sensitive to historical nuances - would seem to forget that it is not societies, their 
institutions and their systems that act, but rather individuals and social groups. Societies, institutions and systems cannot be disconnected from the various ways through which human beings give them meaning, orienting their actions and explaining them. Furthermore, social theories and their theorists are suprahuman entities that simultaneously apprehend the present, past and future of societies.

Nevertheless, to be fair to Jessé Souza, I believe that his perception of Brazil and other modern formations seems to change positively in A tolice da inteligência brasileira, since he returns once more to Weber's ideas in order to argue in favour of the generalizing condition of singular modernization of all societies around the planet. In his critique of what he calls scientific racism, that is, the successful attempt, still at work today, of modernization theory to identify the inhabitants of advanced societies as superior 'people' and the inhabitants of peripheral societies as inferior 'subpeople,' Souza (20I5: 24) argues that this theory left behind, deliberately, the Weberian criticisms of rationalization, especially capitalist rationalization. As well as having ignored the subtleties of Weber's argumentation in relation to the singular and contingent conditions of all historical processes. An example of this singularity, overlooked by the advocates of universal modernization, is the type of hypocritical protestant that constituted North American modernization; the latter is certainly not the same type that set off modernization in England. And if this figure is not the same, this is because the modus operandi of a culture cannot be disconnected from the modus operandi of its corresponding institutions; we cannot argue that particular societies function as formative mirrors for all others. Consequently, the thesis that the cultural singularity of Brazil was responsible for the selective, backward and peripheral type of modernity is clearly rejected by Jessé Souza. He writes: "Today this thesis of Brazilian 'cultural singularity,' imagined in an absolute way as a people with unique and incomparable characteristics - for good or bad - is like a 'second skin' for all Brazilians, intellectuals or otherwise" (Souza, 20I5: 29; original italics).

As we have be seen, Souza rejects the thesis of Brazilian cultural singularity. However, he goes further. He also demonstrates that the condition of singularity that marks each and every process of social formation (European societies, South America, North American society and so on) does not impede us from being able to apprehend, amid their differences, what they share on common. In other words, Souza is interested in apprehending the general through the theoretical and empirical study of social phenomena. To this end, he embarked on a broad and consistent study of contemporary social theory, both national and international, in order to elaborate a "critical theory of modernization" that enables us to comprehend what "is universal in the symbolic reproduction of capitalism as a whole." He critically studied the thought of Florestan Fernandes as, in his view, the only Brazilian theorist able to incorpo- 
rate Brazil within the global analytic framework of capitalism, yet unable to apprehend the subtle mechanisms and hierarchies that align this global reproduction of capitalism. He also explored the ideas of Niklas Luhmann who, though responsible for introducing the theme of social exclusion/inclusion into the debate on global society, remained in tune with the theory of modernization when he explained the high rates of social exclusion in peripheral societies like Brazil by the persistence of premodern tensions in their formation, such as corruption, in a context of dynamic and effective modern institutions.

What, though, allowed Jessé Souza to make progress, I think, in his goal of apprehending the generalizing schema of modern societies is his critique of the limits to Bourdieu's theory. Given the impossibility of reproducing Souza's interpretative schema for the Bourdieusian theory of capitalism here, I shall concentrate on the question that directly interests us: the social disputes for scarce resources, in all capitalist societies, are decided by the differential access to economic, cultural and political capitals. In other words, irrespective of whether we are in England, Mexico or Brazil, the group with school education and intellectually privileged family inheritance (cultural capital) will compose the modern middle class specialized in 'intellectual labour,' in clear contrast to the modern working class responsible for 'manual labour.' In all these societies the schemas naturalizing these social differences are also repeated, premised on the idea that the material privileges and ideals held by the middle class result from the innate talent or merit of individuals. In Souza's view (2015: I54), these schemas function as mechanisms legitimizing social inequalities the world over and, given that they are subtly actualized, require deep critical scrutiny in order to perceive, for example, that the very notion that Brazil is backward and corrupt compared to advanced and 'ethical' societies is one more way of rendering the legitimization of social inequalities increasingly opaque and imperceptible.

Without Bourdieu's theory of capitals, Souza (20I5: I59) argues, the critical insight that capitalism produces social inequalities at a global scale - what he calls their misery and our own - through surreptitious mechanisms of symbolic reproduction would be impossible. Nonetheless, he too falls into the traps of modernization theory when, in his studies of Algeria, he claims that the subproletarian condition of Algerians is due to their rural exodus to the city and, consequently, to the difference in the codes prevailing in the rural and urban worlds. Bourdieu forgot that this condition derives from the fact that the class in question lacks access to the latent premises for economic and social success - that is, to cultural capital. Hence he remained caught up in the analysis of the context of Algerians without paying attention to the universal dimensions that characterize and determine it, just as they characterize and determine the other social contexts worldwide.

Finally, it seems clear to me that in A tolice da inteligência brasileira Jessé Souza releases himself from the tethers that were still binding him to mod- 
ernization theory and the interpretations of atavistic culturalism. The most important result of this endeavour is his productive analysis of the general nature of the schemas involved in the symbolic reproduction of social inequalities that structure advanced capitalism. As I have sought to argue throughout this article, singularity or selectivity designates the diverse and contingent ways through which each social reality actualizes, even institutionally, the everyday disputes between groups for projects of social, political, economic and cultural life. However, these disputes and their realizations compose and reproduce the modus operandi of global capitalism. This does not mean, as is implicitly contained in the assertions of A modernização seletiva, that only the Brazilian experience or those of other societies from the broader configuration of South America are considered singular. What I have tried to make explicit from the outset is that each and every historical and social experience of modernity is eminently singular, insofar as it corresponds to specific cultural, economic and political contexts, as well as the conflicting demands also specific to it. Thus Brazilian modernity is not selective because it developed certain modernizing European elements at the expense of others, and neither did this result from a limited and peripherally articulated arrangement. Rather it occurred as a singular experience. The differences in the experiences resulting from this singularity do not impose a normative understanding of the modern telling us how its processes of events must occur; on the contrary, they inform us, through comparative study, about the conceptual types of society that are scientifically constructed.

Received on 3/I2/2016 | Revised on 6/4/2017 | Approved on I6/8/2017

Edilene Leal has a PhD in Sociology from Sergipe Federal

University (UFS), where she is an assistant professor on its postgraduate course. Her main areas of interest are social theory and social thought. Recent publications include: "Bruno Latour e Michel Foucault: a formação de páticas civilizatórias” (20I6); "Niklas Luhmann e Richard Rorty: contingências e inconsistências" (20I5); "A vigência atual de práticas ético-civilizatórias: uma abordagem a partir de Michel Foucault" (20I4). 


\section{NOTES}

I This article is a reduced version of a text presented at the Social Thought Seminar of the $40^{\text {th }}$ Congress of ANPOCS. I wish to thank Professor André Botelho for his criticisms and suggestions without which this version would not have been possible. I stress, however, that any errors and shortcomings that may still exist are entirely my own responsibility.

2 During the final decades of the twentieth century, the debate on modernity made significant advances, especially through the formulation of historical sociology and, in particular, Shmuel Eisenstadt's theory of multiple modernities. "The basic hypothesis of the multiple modernities approach is that the modern institutional orders (which developed with the institutionalization of the cultural and political orders of modernity) did not develop uniformly around the world - contrary to the presuppositions of the classic modernization theories of the I950s and even the older classic of sociology, like Spencer and, to some extent, Durkheim, which predominated even in Weber's time. Rather they developed in multiple patterns, in models of continually shifting multiple modernities" (Eisenstadt, 20IO: II).

3 Other commentators of Brazil concur with Souza's critique of the atavistic culturalism of the classics and of more recent contributions, including Roberto DaMatta (cited in Neves, 2008: 247): "It is not a question here of a strictly anthropological-cultural problem of Brazil. It is indissociable from the very type of social relations in which the State is bound up in peripheral modernity in general, exceeding the limits of 'national anthropologies' and corresponding cultural singularities." In a similar interpretative vein, Domingues (20II: 7) writes: "We remain concentrated on the reality of our country or, at most, we visit the central countries, Europe and the United States, albeit certainly without pretentions to interpretations that would be valid outside our intellectual borders. In fact, we maintain a complicated relation of identification with them, to a large extent illusory, marked, on the other hand, by a feeling of inferiority (or flights of fancy of a proud Brazilianness, whose defectiveness and precarious- 
ness are fairly self-evident). We need to overcome this, or at least work in this direction, otherwise it makes little sense to even speak of critical theory."

4 "If the form of our culture still remains largely Iberic and Lusitanic, this fact should be attributed primarily to the shortcomings of 'Americanism,' which has thus far been limited largely to a kind of exacerbation of strange manifestations, decisions imposed from outside, beyond the country's borders. The American is still internally nonexistent" (Holanda, I995: I72).

5 According to Roberto DaMatta (I997: 2I): “Thus, we know that the economic ideology founded on the notion of the individual and the idea of the market, a place where everything can be traded, bought and sold, is dominant in western society, and that things are not the same in traditional systems, where the individual and the purely economically are subject to or, as Dumont might say [...], are encompassed by other ideologies that may be religious (the case of India) or political-cultural (the Brazilian and Mediterranean case)."

6 "Freyre's innovative contribution for characterising patriarchal society does not justify, however, as we shall see later, its arbitrary excesses in characterizing the innovative role of the entrepreneurship of the Portuguese colonists and in clinging to the characteristics of cultural plasticity that, he argues, enabled, in addition to acculturation, the social ascension of Blacks, Indians and mestiços. To construct the positive image of the colonists, he opposes the view that the Portuguese coming her were 'the worst elements' (prisoners, convicts, etc.). On the contrary, people from good stock also came and many of them gave rise to the great patriarchal families" (Cardoso, 2013).

7 According to Antonio Candido (I998 85-86), "Sérgio Buarque de Holanda had not read Manoel Bonfim and his position is different, but, like him, in Raízes do Brasil he does not express any saudosismo, any longing or nostalgia, nor limit himself to the family as the structure of reference, and seeks to extract from the past a lesson that averts conservative positions in the present. We could say that for the absolute majority of analysts of the past at his time, 
including Oliveira Viana and Gilberto Freyre, the Luso-Brazilian dimension of colonial origin was seen above all in terms of its continuity, while Sérgio focused above all on its rupture, on its redefinition through the 'revolution' represented by the end of the slavery regime in I888. Given this fact, we could ask whether books like Populações Meridionais do Brasil and Casa-Grande \& Senzala represent, in some aspects, a certain reaction or resistance to the transition from the old Brazil to the new Brazil that Sérgio Buarque de Holanda calls 'American'? Perhaps."

8 As Dante Moreira Leite emphasizes, "Freyre's work reveals a deep fondness for the black. But for the enslaved black, the one who knew his or her place - as an urchin from the manor house, as the punchbag for a rich kid, as a cook, as a wet nurse or as a lady's housemaid. [...] The contemporary documents of slavery [...]far from justify the idea of a sweetness in the relations between masters and slaves." Leite, D. M. O Caráter Nacional do Brasileiro: história de uma ideologia. São Paulo Ática, I992, p.28I. Along the same lines, Ademir Gebara unmasks this idyllic relation between master and slave sustained by Freyre, who went as far as to absurdly claim that it was better be a slave in Brazil than a factory worker in Europe in the nineteenth century. On the resistances of slaves in Brazil (especially the escapes and suicides) and the 'docile' legislation to suppress attempts to escape, see: Gebara, A. O Mercado de Trabalho Liure no Brasil (I87I-I888), p. I36-7 and I47. In fact, Freyre himself admits that the life of black people, slaves of the white ioiôs and iaiás, was not all joy. There were those who killed themselves eating earth, hanging themselves, poisoning themselves with the herbs and brews of sorcerers. The beam ended the life of many."

9 "For this purpose, though, making use of Sérgio Buarque de Holanda's ideas would appear much more fruitful than those of Gilberto Freyre, since despite Jessé Souza emphasizing that he intends to 'use Freyre against Freyre' and focus solely on the descriptive aspects of his work without sharing the generalizations reached by the author of Casa-Grande \& Senzala, it can be observed that resorting to the author's work is not devoid of problems" (VillasBôas Filho, 2009: 306). 
Io According to one of the most important commentators of Sérgio Buarque de Holanda's work, Maria Odila Leite da Silva Dias (I998: 23): "The radicalism of the diagnoses of the possibilities for change in Brazilian society was enunciated clearly and without illusions concerning the difficulties of the process in Raízes do Brasil, his first book, begun in 1927 and published in 1936. The abolition of slavery, the construction of railways, urban transport and above all city growth foreshadowed ruptures with the colonial, slave regime roots, with the Portuguese legacy of an eminently authoritarian, hierarchized and conservative society of acquired privileges. Both in the Northeastern sugar plantations and in the coffee economy, labour relations were transformed and became more like the relations characterizing the centres of industrial exploration with all that this process implied in terms of tensions and latent conflicts, especially in the province of São Paulo where the arrival of European immigrants fostered a previously absent social diversity."

I I See, for example, Neves (2008) and Domingues (20II).

\section{BIBLIOGRAPHY}

Badie, Bertrand. (I992). Análisis comparado y sociología histórica. Revista Internacional de Ciencias Sociales, I33, p. 34I-350.

Blaj, Ilana. (1998). Sérgio Buarque de Holanda: historiador da cultura material. In: Candido, Antonio (org.). Sérgio Buarque de Holanda e o Brasil. São Paulo: Fundação Perseu Abramo.

Botelho, André \& Schawarcz, Lilian. (orgs.). (2009). Um enigma chamado Brasil: 29 intérpretes e um país. São Paulo: Companhia das Letras.

Bourdieu, Pierre. (20II). A distinção: crítica social do julgamento. 2 ed. Porto Alegre: Zouk.

Campante, Rubens Goyotá. (2003). O patrimonialismo em Faoro e em Weber e a sociologia Brasileira. Dados - Revista de Ciências Sociais, Rio de Janeiro, 46/I, p. I53-I93.

Candido, Antonio. (1998). A visão política de Sérgio Buarque de Holanda. In: Sérgio Buarque de Holanda e o Brasil. São Paulo: Fundação Perseu Abramo. 
Cardoso, Fernando H. (2013). Pensadores que inventaram o Brasil. São Paulo: Companhia das Letras.

Cohn, Gabriel. (2004). Indiferença, nova forma de barbárie. In: Novaes, Adauto. (org.). Civilização e barbárie. São Paulo: Companhia das Letras.

Cohn, Gabriel. (2002). O pensador do desterro. Folha de S. Paulo. São Paulo, Caderno Mais.

Damatta, Roberto. (1997). Carnavais, malandros e heróis: para uma sociologia do dilema brasileiro. 6 ed. Rio de Janeiro: Rocco.

Damatta, Roberto. (I984). O que faz o brasil, Brasil? Rio de Janeiro: Rocco.

Dias, Maria Odilia. (1998). Política e sociedade na obra de Sérgio Buarque de Holanda. In: Candido, Antonio (org.). Sérgio Buarque de Holanda e o Brasil. São Paulo: Fundação Perseu Abramo.

Domingues, José Maurício. (20II). Teoria crítica e semi(periferia). Belo Horizonte: Ed. UFMG.

Eisenstadt, Sahmuel. (20I0). Modernidade japonesa: a primeira modernidade múltipla não ocidental. Dados - Revista de Ciências Sociais, 53/I, p. II-54.

Eisenstadt, Sahmuel. (I992). El marco de las grandes revoluciones: cultura, estructura social, historia e intervención humana. Revista Internacional de Ciencias Sociales, I33, p. 4II-428.

Eisenstadt, Sahmuel. (I979). Revolução e a transformação das sociedades. Rio de Janeiro: Zahar.

Eisenstadt, Sahmuel. (I969). Múltiplas modernidades: ensaios. Lisboa: Livros Horizonte.

Eisenstadt, Sahmuel. (I968). Modernização e mudança social. Belo Horizonte: Editora do Professor.

Elias, Norbert. (I997). Os alemães. Rio de Janeiro: Zahar.

Elias, Norbert. (I994). O processo civilizador, v. I. Rio de Janeiro: Zahar.

Elias, Norbert. (I993). O processo civilizador, v. II. Rio de Janeiro: Zahar.

Faoro, Raimundo. (200I). Os donos do poder: formação do patronato político brasileiro. zed. São Paulo: Globo. 
Faoro, Raimundo. (1998). Sérgio Buarque de Holanda: analista das instituições brasileiras. In: Candido, Antonio (org.). Sérgio Buarque de Holanda e o Brasil. São Paulo: Fundação Perseu Abramo.

Foucault, Michael. (2008). Estruturalismo e pós-estruturalismo (1983). In: Motta, Manoel Barros da. Ditos \& escritos: arqueologia das ciências e história dos sistemas de pensamento, v. II. Tradução de Elisa Monteiro. 2 ed. Rio de Janeiro: Forense.

Foucault, Michael. (2002). As palauras e as coisas. São Paulo: Martins Fontes.

Foucault, Michael. (I996). A ordem do discurso. São Paulo: Edições Loyola.

Freud, Sigmund. (2010). O mal-estar na civilização. In: Obras Completas, v. I8. São Paulo: Companhia das Letras.

Freyre, Gilberto. (1992). Casa-grande \& senzala. Rio de Janeiro: Record.

Holanda, Sérgio Buarque. (I995). Raízes do Brasil. São Paulo: Companhia das Letras.

Holanda, Sérgio Buarque. (I994). Visão do paraíso. São Paulo: Brasiliense.

Jameson, Frederic. (2005). Modernidade singular: ensaio sobre a ontologia do presente. Rio de Janeiro: Civilização Brasileira. Kant, Imannuel. (2004). Ideia de uma história universal de um ponto de vista cosmopolita. 2ed. São Paulo: Martins Fontes.

Kant, Imannuel. (I974). Textos seletos. In: Resposta à pergunta: o que é esclarecimento? Petrópolis: Vozes.

Luhmann, Niklas. (1997). Observaciones de la modernidad: racionalidad y contigencia em la sociedad moderna. Buenos Aires: Paidós.

Marx, Karl. (I997). O I8 Brumário de Louis Bonaparte. Rio de Janeiro: Hucitec.

Neves, Marcelo. (2008). Entre Têmis e Leviatã: uma relação difícil. São Paulo: Martins Fontes.

Oliveira, Luiz Alberto. (2004). Um corpo estranho: civilização e pós-humanismo. In: Novaes, Adauto (org.). Civilização e barbárie. São Paulo: Companhia das Letras.

Rorty, Richard. (2007). Contingência, ironia e solidariedade. São Paulo: Martins Fontes. 
Schwarz, Roberto. (20I4). As ideias fora de lugar. São Paulo: Companhia das Letras.

Souza, Jessé. (2015). A tolice da inteligência brasileira: ou como um país se deixa dominar por uma elite. São Paulo: LeYa. Souza, Jessé. (20II). A ralé brasileira: quem é e como vive. Belo Horizonte: Ed. UFMG.

Souza, Jessé. (2006). A construção social da subcidadania: para uma sociologia política da modernidade periférica. Belo Horizonte: Ed. UFMG.

Souza, Jessé. (2000a). A modernização seletiva: uma interpretação do dilema brasileiro. Brasília: Ed. UnB.

Souza, Jessé. (200ob). Democracia racial e multiculturalismo: a ambivalente singularidade cultural brasileira. Estudos Afro-Asiáticos, 38, p. I35-I55.

Souza, Jessé. (I999). A ética protestante e a ideologia do atraso brasileiro. In: O malandro e o protestante: a tese weberiana e a singularidade cultural brasileira. Brasília: Ed. UnB. Tavolaro, Sérgio. (2005). Existe uma modernidade brasileira? Reflexões em torno de um dilema sociológico brasileiro. Revista Brasileira de Ciências Sociais. São Paulo, 20/59, p. 5-22.

Tocqueville, Alexis de. (2005). A democracia na América. São Paulo: Martins Fontes.

Vandenberghe, Fredéric. (2006). Construção e crítica da nova sociologia francesa. Sociedade e Estado, Brasília, 2I/2, p. 315-366.

Veyne, Paul. (2009). Foucault: his thought, his character. Cambridge: Polity Press.

Veyne, Paul. (1983). The inventory of diferences. Economy and Society, II/2, p. I73-I98.

Viana, Luís Werneck. (I999). Weber e a interpretação do Brasil. In: Souza, Jesse. (org.). O malandro e o protestante: a tese weberiana e a singularidade cultural brasileira. Brasília: Ed. UnB.

Villas-Boas Filho, Otávio. (2009). Teoria dos sistemas e o direito Brasileiro. São Paulo: Saraiva.

Weber, Max. (2002) Economia y sociedad. México: Fondo de Cultura Económica. 
Weber, Max. (200I). The protestant ethic and the spirit of capitalism. New York: Routledge.

Weber, Max. (1998). A ética protestante e o espírito do capitalismo. I4 ed. São Paulo: Pioneira.

Weber, Max. (I982). Rejeições religiosas do mundo e suas direções. In: Ensaios de Sociologia. 5 ed. Rio de Janeiro: LTC/ Editora.

Wegner, Robert. (I999). Os Estados Unidos e a fronteira na obra de Sérgio Buarque de Holanda. In: Souza, Jesse. (org.). O malandro e o protestante: a tese weberiana e a singularidade cultural brasileira. Brasília: UNB.

Wittgenstein, Ludwing. (I995). Tratado lógico-filosófico/investigações filosóficas. Lisboa: Fundação Calouste Gulbenkian. 


\section{JESSÉ SOUZA: UMA RECAÍDA NA INTERPRETAÇÃO DE MODERNIDADE UNIVERSAL?}

\begin{abstract}
Resumo
Trata-se de discutir a interpretação de Jessé Souza sobre o Brasil a partir de dois argumentos interligados. O primeiro, apresentado na primeira parte, é a ideia de que Jessé Souza, em A modernidade seletiva absorve, acriticamente, certa ambiguidade presente na teoria de Max Weber da racionalização moderna. Isto é, as concepções weberianas de que as singularidades definem o processo de formação de sociedades modernas, e de que o modelo de sociedade europeia se expandiria para todos os cantos do mundo orientam a crítica do autor à interpretação clássica de que a modernidade brasileira é atávica. O segundo argumento é uma consequência lógica do primeiro, pois pretende mostrar que seu conceito de modernidade seletiva incorre no equívoco semelhante de supor um ideal de modernidade no qual o Brasil, como realidade histórica, deveria se espelhar.
\end{abstract}

\section{JESSÉ SOUZA: A RELAPSE INTO THE INTERPRETATION OF UNIVERSAL MODERNITY?}

The purpose of this paper is to discuss Jessé Souza's interpretation of Brazil. To this end I develop two interrelated arguments. The first, presented in the first part, is the idea that Jessé Souza in Selective modernity uncritically absorbs a certain ambiguity present in Max Weber's theory of modern rationalization: namely, the Weberian idea that, on the one hand, singularities define the process of formation of modern societies, and, on the other, the European model of society would expand to all parts of the world. These orient Jessé Souza's critique of the classical interpretation that Brazilian modernity is atavistic. The second argument is a logical consequence of the first, intending to show that his concept of selective modernity makes the same mistake of assuming an ideal of modernity upon which Brazil, as a historical reality, should model itself.
Palavras-chave

Modernidade; modernidade seletiva; modernidade universal; modernidade brasileira; Jessé Souza.
Keywords

Modernity;

selective modernity; universal modernity; Brazilian modernity; Jessé Souza. 